\title{
Investigation of Perfectionism and Self-Esteem Scores of Gifted and Average Students
}

\author{
Marilena Z. LEANA-TAȘCILAR* \\ Esra KANLI ${ }^{* *}$
}

\begin{abstract}
The purpose of the study is to investigate gifted and average students' perfectionism and self-esteem. The sample consists of 53 gifted and 31 average students who were 2nd and 3rd graders. Data were derived from the WISC-R Intelligence Test, Positive and Negative Perfectionism Scale and Culture Free SelfEsteem Scale for Children. For the total sample, the results revealed that while self-esteem showed difference regarding gender and intelligence, perfectionism did not present any difference. However, regarding the total sample it was found out that girls' positive perfectionism scores were higher than boys. Another important finding of this study was the negative relation between self-esteem and negative perfectionism. The findings highlighted the importance of curriculum for perfectionism and self-esteem levels.
\end{abstract}

Key words: Gifted Children, Perfectionism, Self-esteem, WISC-R, IQ

\footnotetext{
Assist. Prof. Dr., Istanbul University, Hasan Ali Yucel Faculty of Education, Special Education Department, Gifted Teacher Training Program, Istanbul, Turkey. E-mail: mleana@istanbul.edu.tr

Res. Assist. Dr., Istanbul University, Hasan Ali Yucel Faculty of Education, Special Education Department, Gifted Teacher Training Program, Istanbul, Turkey. E-mail: ekanli@istanbul.edu.tr
} 


\section{SUMMARY}

Purpose and Significance: This study compares perfectionism and selfesteem scores of gifted and average students. Perfectionism is regarded as a characteristic of gifted learners. Self- esteem is a person's overall evaluation or appraisal of her/his own worth. Therefore, it is vital to understand the effect of intelligence levels on the concepts of perfectionism and self-esteem. Moreover, the effect of gender on these two concepts was also examined in the study.

Method: Descriptive research methodology was used in the study. As the study was carried out with special group of students, researchers didn't select a sample for the study and the research was conducted with a study group. A total of 84 students (53 gifted and 31 average), from a project school participated in the study. In this project school, all the students enrolled in a special education program that aimed to cover their cognitive and emotional needs. Students' intelligence levels were measured by using Weschler Intelligence Scale for Children-Revised (WISC-R); perfectionism and self-esteem scores were derived from two scales namely, PositiveNegative Perfectionism Scale and Culture-Free Self-Esteem Inventories (CFSEI-2).

Results: Results showed that students' self-esteem levels changed according to gender and intelligence scores. It was found that gifted students' self-esteem levels are higher than average students and this difference is statistically significant. Moreover in the total group, boys' selfesteem scores are higher than girls and this result is statistically significant, too. Briefly, it was observed that intelligence did not affect perfectionism. No significant difference was observed between gifted and average students. Furthermore, it was found out that gender affected the levels of perfectionism; girls' positive perfectionism scores were significantly higher than boys.

Discussion and Conclusions: In the literature some of the researchers have dominated views that the gifted learners are negative perfectionists. Although the sample size of the study is a limitation for making that kind of generalizations, the results of this study showed that the gifted learners could be positive perfectionists and have higher self-esteem levels. However, these results should be evaluated in the context of the study because all the gifted learners in this study have been receiving special education. Thus, their needs are being met. When the gifted learners receive appropriate education, they will have positive characteristics and maximize their potentials, too. It can be concluded that gifted learners should be given differentiated education that is appropriate for their needs. 


\title{
Üstün Zekalı ve Normal Gelişim Gösteren Çocukların, Mükemmeliyetçilik ve Öz-Saygı Düzeylerinin İncelenmesi
}

\author{
Marilena Z. LEANA -TAŞCILAR* \\ Esra KANLI**
}

\begin{abstract}
ÖZ. Araştırma, üstün zekalı ve normal gelişim gösteren çocukların, mükemmeliyetçilik ve öz-saygı düzeylerinin incelenmesini amaçlamaktadır. Çalışma İstanbul Üniversitesi Hasan Ali Yücel Eğitim Fakültesi, Özel Eğitim Bölümü tarafından "Üstün Zekalı Çocukların Eğitimi Projesinin” yürütüldüğü bir devlet okulunda yürütülmüştür. Örnekleme ilköğretim 2. ve 3 . sınıf öğrencilerinden 53 üstün zekalı ve 31 normal gelişim gösteren toplam 84 öğrenci dahil edilmiştir. Veriler 'Wisc-R Zeka Testi', “OlumluOlumsuz Mükemmeliyetçilik Ölçeği” ve "Kültürden Arındırılmış Çocuklar İçin Öz-saygı Envanteri” kullanılarak toplanmıştır. Sonuçlar öz-saygının, cinsiyete ve zekaya bağlı olarak değişirken mükemmeliyetçiliğin zekaya bağlı olarak değişmediğini buna karşın kızların olumlu mükemmeliyetçilik puanlarının erkeklerden yüksek olduğunu göstermiştir. Bulgular, sosyo-duygusal eğitim programının mükemmeliyetçilik ve öz-saygı düzeylerine olan etkisinin önemini ortaya koymuştur.
\end{abstract}

Anahtar Sözcükler: Üstün Zekalı Çocuklar, Mükemmeliyetçilik, Öz-sayg1, WISC-R, ZB

\footnotetext{
Yrd. Doç. Dr., İstanbul Üniversitesi, Hasan Ali Yücel Eğitim Fakültesi, Özel Eğitim Bölümü, Üstün Zekalıların Eğitimi ABD, E-mail: mleana@istanbul.edu.tr

** Arş. Gör. Dr., İstanbul Üniversitesi, Hasan Ali Yücel Eğitim Fakültesi, Özel Eğitim Bölümü, Üstün Zekalıların Eğitimi ABD, E-mail: ekanli@istanbul.edu.tr
} 


\section{GİRIŞ}

Zeka, psikoloji biliminin uzun y1llardır üzerinde en çok araştırma yaptığı kavramlardan biridir. Alanyazın incelendiğinde pek çok farklı zeka tanımının yapıldığını görmekteyiz. Bazı araştırmacılar zekayı öğrenme ve öğrendiklerini kullanma yeteneği olarak tanımlarken (Bknz. Clark, 2002), bazıları zekayı öğrenilenleri problem çözmede kullanma yeteneği olarak görür (Maker, 2003). Her iki tanımda ortaya konulan zeka ifadesinin insan zekasını karşılamadığı ortadadır, zira insan dışındaki bazı canlılar da öğrenebilir ve öğrendiklerini karşılaşılan problemleri çözmede kullanabilir. Birçok uzman, insanı diğer canlılardan ayıran ve farklı kılan en önemli özelliğinin muhakeme etme yeteneği olduğu konusunda hem fikirdir (Bknz. Sternberg, 1997).

Zeka ile ilgili literatürde bulunan ve her geçen y1l yeni araştırma ve bulguların 1şığında sayıları artan farklı tanım ve teoriler yer almaktadır. Zeka kavramı tek bir boyut, tek bir tanım, tek bir yaklaşım üzerinden açıklanamamaktadır. Bu durum kaçınılmaz olarak üstün zeka kavramını da etkilemektedir. Zeka tanımları üzerinde fikir birliğine varılamadığı gibi alanda çalışan bilim insanları üstün zeka kavramını da tek bir tanım altında toplayamamakta ve çeşitli zeka tanım ve teorileri ortaya koymaktadırlar.

Marland Raporuna göre, üstün performans gösteren bireyler bazı yetenek veya özelliklerin birleşimlerini gösterirler. $\mathrm{Bu}$ yetenekler arasında genel zihinsel yetenek, özel akademik yetenek, yaratıcı veya üretken düşünme, liderlik yeteneği, görsel ve performansa dayalı sanat yeteneği, psikomotor yetenek sayllabilir. (Akt. Kanl1, 2007). Maker (2003) ise, üstünlügün sadece yüksek zeka bölümü ile değerlendirilmesine karş1 çıkmış ve üstünlüğün temel bileşenleri arasında ilgiler, istekler ve karmaşık problemleri çözme yeteneğinin olduğunu söylemiştir.

Renzulli (1986) üstün zekalılığı genel ve özel yetenek düzeyi, yaratıc1lık ve motivasyon olmak üzere üç kümenin kesişim noktası olarak görmektedir. Genel yetenekler, sözel ve sayısal muhakeme, soyut düşünebilme ve bilgilerin seçici anımsanması gibi yetenekleri içerirken; özel yetenek daha çok resim, dans gibi sanat alanında ya da fen, matematik gibi daha teknik alandaki yetenekleri kapsar. Yaratıcılık, yeni fikirler oluşturabilme ve esnek düşünme gibi süreçleri içerirken; motivasyon ise üstün iş görev üstlenme yeteneğidir. Renzulli, üstün bir bireyin bu üç özellik kümesinin kesiş̧iği noktada yer aldığını savunmaktadır (Akt. Davaslıgil, 2004). Modern zeka kuramcilarından olan Sternberg (2003) ise sentezci (problemleri tanıma, tanımlama ve temsil etme), deneysel (değerlendirme ve sergileme) ve bağlamsal (çevreye uyum gösterme, var olan çevreyi değiştirme ve uyumun başarısız olduğu zamanlarda farklı bir çevre seçme) özelliklerden bahsetmektedir. $\mathrm{Bu}$ bileşenlere analitik, yaratıcı ve pratik yetenekler de eklenmektedir. 
Üstün zeka karmaşık bileşenlerden oluşmaktadır ve bu durum da üstün zihinsel yeteneğe sahip bireylerin gelişim süreçlerinin normal zihinsel yeteneğe sahip bireylerden farklı olacağını göstermektedir. Üstün zekalı çocukların özellikleri, zihinsel, fiziksel, sosyal ve kişilik gibi farklı boyutlarda incelenmektedir (Leana ve Cinan, 2012). Bu özellikler arasında, yüksek öz güven, içten denetim, adalet duygusu, haksızlıklara karş1 duyarlılık, kaderci olmama ve sebat gibi özellikler sayılabilir (Robinson ve Clinkenbeard, 1998).

Üstün zekalı çocukların farklı duygusal ve zihinsel gelişimlerine bağlı olarak öz-sayg1 düzeylerinin de normal gelişim gösteren yaşıtlarına göre farklı olduğu düşünülmektedir. Nitekim, Kramer (1988) ve Roberts ve Lowett'tin (1994) araştırma bulgularına göre, üstün zekalı ergenler normal gelişim gösteren yaşıtlarına göre daha fazla mükemmeliyetçilik özelliği sergilemektedir (Akt. Saranlı ve Metin, 2012). Konu ile ilgili Türkiye'deki çalışmalara bakıldığında daha çok ergenlerle çalışıldığ 1 fark edilmektedir (Mısırlı-Taşdemir, 2003; Bencik, 2006). Bu bağlamda mevcut araştırmanın amacı, küçük yaştaki (ilköğretim düzeyinde) üstün zekalı ve normal gelişim gösteren çocukların mükemmeliyetçilik ve öz-saygı düzeylerini incelemek ve bu bağlamda yerli alanyazına katkı sağlamaktır.

\section{Mükemmeliyetçiliğin Tanımı ve Yapısı}

Büyüme ve gelişme döneminde çocuğun davranışları eleştirilerek, düzeltilerek ve ödüllendirilerek kişisel ve toplumsal beklentilere uygun davranmayı öğrenmesi konusunda sürekli olarak yönlendirilmektedir. Çevresel şartların oluşturduğu baskı neticesinde pek çok kişi belirli standartlara ulaşma çabası içerisinde olmaktadır. Alanyazında mükemmeliyetçiliğe farklı yaklaşımlar ve farklı tanımlar yer almaktadır.

Litauer ve Litauer (1997), bireyin kendisine ve diğerlerine yönelik yüksek standartlar belirlemesini ve her şeyin, her zaman düzen içerisinde olmasını istemeyi "mükemmeliyetçilik" olarak tanımlamaktadırlar. Hollingworth (1942), üstün zekalı çocukların özelliklerini ortaya koymak için çok yüksek zihinsel düzeye sahip (180 IQ) 12 tane (8 erkek, 4 kız) üstün zekalı çocukla yaptığ gerektiği, toplumsal olarak dışlanmak riskiyle karşı karşıya kaldıkları ve duygusal olarak hazır olmadıkları halde önemli felsefik ve etik sorularla yüzleşmek zorunda kalmalarının sorun yarattığı sonuçlarına varmıştır. Hollingworth bu çalışmalarında $(1926,1942)$ mükemmeliyetçiliği, ilk defa üstün zekalı bireylerin duygusal özelliklerinden biri olarak kabul etmektedir. Davis'e (2006) göre üstün zekalı mükemmeliyetçi bireyler, her zaman daha iyisinin yapılabileceğine inandıkları için performanslarından memnun olmamaktadırlar. 
Üstün zekalı bireyler göz önünde bulundurulduğunda mükemmeliyetçiliğin onların eş zamanlı olmayan gelişimlerinin bir sonucu olduğu düşünülmektedir. Zihin, bedenden daha hızlı geliştiği için, sonuca varma özellikleri ve değerleri yaşıtları ile değil, zihinsel açıdan benzerleri ile aynıdır. Bu gelişiminin farkında olan üstün zekalı çocuk kendine ulaşılması zor ölçütler belirler, ancak henüz bedeni yeteri kadar gelişmiş olmadığ 1 için beynin ihtiyaçlarını karşılayamaz ve böylece cesareti kırılır (Silverman, 1993).

Yüksek mükemmeliyetçilik düzeylerine sahip olan bireyler kendilerine çok yüksek standartlar koymaları ve performanslarına karşı aşırı eleştirel yaklaşmaları ile karakterize edilirler (Frost, Marten, Lahart, ve Rosenblate, 1990). Bu durumun hem olumlu hem de olumsuz sonuçları vardır; yüksek standartlara sahip olmanın yüksek motivasyon ve başarı gibi olumlu sonuçları olabilirken (Bieling, Israeli, Smith ve Antony, 2003), kendine karş1 aşırı eleştirel olma bireyde yetersizlik hissine, özgüven kaybına ve hatta depresyona sebebiyet verebilmektedir. Üstün zekalılarla çalışan pek çok uzman için sağl1klı mükemmeliyetçilik oksimoron olarak nitelenmektedir (Greenspan, 2000).

Mükemmeliyetçilik son yıllarda araştırmacılar tarafından daha da artan bir fikir birliği ile çok boyutlu bir yapı olarak tanımlanmaktadır. Fakat hâlihazırda bu çok boyutlu yapıyı oluşturan parçalarla ilgili ortak bir tanıma erişilememiş̧tir. Araştırmalar olumlu/sağlıklı, olumsuz/sağlıksız (Silverman, 1999; Schuler, 2000), uyumlu, uyumsuz (Parker, 2000) formlarından bahsetmektedir.

\section{Mükemmeliyetçi Kişinin Özellikleri}

Mükemmeliyetçi insanlarda en çok görülen algılama bozukluklarından birisi "ya hep ya hiç" tarzı düşünmedir. Bu düşünce tarzında kişi "doğru" ile "yanlış" arasında pek çok derece bulunabileceğini düşünmeden, olayları sadece doğru ve yanlış olarak sınıflama eğilimindedir. Yüksek standartlar belirlemek, depresyon, anksiyete ve öfke doğurabilmektedir. Başkalarının davranışlarıyla ilgili düşüncelere öfke eşlik edebilirken, kişinin kendisiyle ilgili bu tip düşüncelerine anksiyete, depresyon ve yetersizlik hisleri eşlik etmektedir (Antony ve Swinson, 2000).

Üstün zekalı mükemmeliyetçi bireyler kendilerinin ve çevrelerinin beklentilerini karşılayabilmek adına performanslarına aşırı önem verebilirler. $\mathrm{Bu}$ da onlarda "her zaman her şeyin en iyisini yapmalıyım" tarzı bir aksak düşüncenin gelişmesine sebebiyet verebilir. Üstün zekalı çocuklarda mükemmeliyetçilik bazı durumlarda kendini beklenmedik başarısızlık olarak da gösterebilmektedir (Davis, 2006). 
Önemli bir kişilik özelliği olarak kabul edilen mükemmeliyetçiliğin, üstün ve normal gelişim gösteren bireylerde nasıl farklılaştığının daha ayrıntılı bir şekilde incelenmesi gerektiği düşünülmektedir. Bununla birlikte bireylerin gelişimlerini etkileyen ve ilgi duyulan bir diğer konu da, kişinin kendine verdiği değer, yani öz-saygıdır.

\section{Öz-saygı Nedir?}

Öz-sayg1, psikolojik olarak varolabilmek için temel bir etmendir. Duygusal yaşantının olmazsa olmazlarındadır. $\mathrm{Bu}$ nedenle de oldukça araştırılan bir kavram olan öz-saygıya ilişkin alanyazında farklı tanımların yapıldığı görülmektedir. Yapılan tüm tanımlamalarda, öz-saygı kavramının üç kavramla ilişkilendirilerek açıklanmaya çalışıldığı görülmektedir. $\mathrm{Bu}$ terimler "benlik kavramı", "ideal benlik kavramı" ve "benlik imgesi" kavramlarıdır (Akan, 2001).

Diğer terimleri kapsayıcı nitelikte olan benlik kavramını, James (1948), benliği kişinin kendisinin farkında olması olarak tanımlamaktadır. James, 'öz' ü en genel anlamıyla, bir insanın kendisi olarak tarif etmiştir. Yani, kendi vücudu, özellikleri, kabiliyetleri, sahip olduğu şeyler, arkadaşları, ailesi ve düşmanları gibi.

\section{Düşük ya da Yüksek Öz-saygıya Sahip Bireylerin Özellikleri}

Pope, McHale ve Craighead'e (1988) göre, öz-saygı algılanan kişilik, kişilik kavramı ve ideal kişilik arasındaki farklılıklardan ortaya çıkar. Farklılığın fazla olması öz-saygının düşük olduğunu, az olması ise özsaygının genellikle yüksek olduğunun göstergesidir (Akt. Avşaroğlu, 2007). Bireyi kendisini geliştirmesi konusunda motive eden de aradaki bu farktır. Ancak bu farklılık bireyin kendisinin ve etrafindaki kişilerin beklentilerini karşılayamıyorsa endişe ve stres yaratan durumlara neden olmaktadır. Lawrence (2006) bu durumu, gerçek dışı beklentilerin düşük özsaygıya; beklentilerin olmamasının da başarısızlığa neden olduğu şeklinde açıklamaktadır.

Benlik saygısı düşük olan bireyler, daha çok onay gördükleri ortamları tercih eder ve olumsuz değerlendirmelerden hoşlanmaz. Dolayısıyla onay beklentilerini karşılamayan ortamları tercih etmezler. Bu bağlamda düşük özsayg1, endişe, mutsuzluk, utanma gibi durumlarla negatif ilişki sergilemektedir. Öte yandan, tüm bunların sadece olumsuz olarak değerlendirilmemesi gerektiği, tam tersi bu durumların bazı bireylerin baş etme mekanizmalarını kuvvetlendirdiğini de savunulmaktadır (Jones, 1973). 
Öz-saygının gelişmesini etkileyen temel etmenler arasında aile, okul, akademik başarı ve sosyoekonomik durum yer almaktadır. Kendisini ailesinin değerli bir üyesi olarak hisseden, ailesine katkıda bulunan, ebeveynlerinden ve kardeşlerinden gördüğü sevgi ve sayg1 konusunda kendisini güvende hisseden bir çocuk bu ailesel alanda oldukça olumlu özsaygıya sahip olacaktır (Pope, McHale ve Craighead, 1988).

Alanyazındaki mükemmeliyetçilik ve öz-saygı ile ilgili bu bilgiler çok değerlidir. Bununla birlikte alan yazında bu iki kavram zeka ve cinsiyet değişkenlerine göre ele alındığında çelişkili sonuçların olduğu görülmektedir. $\mathrm{Bu}$ noktada özellikle mükemmeliyetçilik açısından bakıldığında, kavramın içerdiği çok boyutlu yapı dolayısıyla alan yazında üstün zekalı bireylerin önemli bir kişilik özelliği olarak görülmekte (Silverman, 1999; Davis, 2006) ve bireylerin bu kavramı yaşantılama deneyimlerine bağlı olarak olumlu ya da olumsuz olarak değerlendirilmektedir. Öyle ki, uzmanların bir kısmı mükemmeliyetçiliğin öz-saygıyı, motivasyonu ve başarıyı arttırma gibi etkilerinden bahsederken (Rice, Ashby ve Slaney, 1998), diğer uzmanlar mükemmeliyetçiliği kayg1 düzeyini artırma, özgüven kaybı ve hatta depresyona girme gibi sonuçlarından dolayı önemli bir sorun olarak görmektedir (Chan, 2003; Orange, 1997). Bu araştırmalardan çıan sonuçlar, üstün yetenekli çocuklarda mükemmeliyetçiliğin derecesinin dengede tutulmasının gerekliliğini ve olumsuz mükemmeliyetçilik özelliklerinin yerini olumlu mükemmeliyetçilik özelliklerinin almasının önemini vurgulamaktadır. Alan yazındaki çalışmalar irdelendiğinde bazı araştırmaların zeka düzeyi ve mükemmeliyetçilik arasında ilişkiler bulguladıkları gözlenirken (LoCicero ve Ashby, 2000; Baker, 1996), farklı araştırmalar mükemmeliyetçilik düzeyinin daha çok cinsiyete bağlı olarak değiştiğini ortaya koymuşlardır (Oran-Pamir, 2008). Benzer şekilde öz-saygı kavramı ile ilgili yapılan araştırmalar da muhtelif sonuçlar içermektedir. Kelly ve Colangelo (1984) zekanın öz-saygıyı olumlu şekilde etkilediğini ifade ederken, farklı araştırmacılar (Loeb ve Jay, 1987; Burak, 1995) anlamlı bir fark bulgulamadıklarını ifade etmişlerdr. Öz-saygı ve cinsiyet arasındaki ilişkileri inceleyen araştırmaların sonuçlarında da benzer ihtilaflı bulgulara erişilmiştir (Bencik, 2006; Lea-Wood, 1995). Her ne kadar alanyazında zeka, mükemmeliyetçilik ve öz-saygı düzeylerinin birbirini etkilediği ifade edilmiş olsa da, bu kavramların tamamını birlikte inceleyen çalışmaların sonuçları ihtilaflı ve sayısı sınırlıdır, aynı zamanda çalışmaların gerçekleştirildiği örneklem gruplarının yaş aralığı genellikle ergenleri kapsamaktadır. Bu bağlamda mevcut araştırmada hedeflenen bu çelişkili bulgulara netlik kazandırmak amacıyla, ilköğretim düzeyi üstün zekalı ve normal gelişim gösteren çocukların mükemmeliyetiçilik ve öz-saygı düzeylerini incelemek ve bu bağlamda özellikle yerli alanyazına katkı sağlamaktır. 


\section{YÖNTEM}

\section{Çalışma Grubu}

$\mathrm{Bu}$ araştırmada üstün zekalı çocuklar, normal gelişim gösteren akranlarıyla karşılaştırılmaktadır. Bu sebeple çalışma grubu belirlenirken yakınlık ve erişim kolaylığı sağlaması bakımından amaçlı örnekleme yöntemlerinden kolay ulaşılabilir örnekleme yöntemi (Şimşek ve Yıldırım, 2008) benimsenmiştir. Araştırma, İstanbul Üniversitesi ve MEB arasında imzalanan protokol gereği eğitime devam eden ve üstün zekalı öğrencileri normal gelişim gösteren yaşıtlarından ayırmadan karma bir eğitim programı benimseyen bir pilot okulda gerçekleştirilmiştir. Öğrencilerin farklı bilişsel ve duyuşsal özellikleri dikkate alınarak uygulanan eğitim programında düsünme becerileri, yaratıcı düşünme ve sosyal-duygusal gelişim dersleri normal MEB müfredatına ek olarak birinci sınıftan itibaren, her hafta ek üç ders saati olarak okutulmaktadır. Çalışma grubuna, bu pilot okula devam eden 42 2. sınıf, 42 3. sınıf toplamda 84 öğrenci dahil edilmiştir (Tablo 1.).

\section{Veri Toplama Araçları}

WISC-R Çocuklar İçin Zeka Ölçeği. Öğrencilerin zeka düzeylerini belirlemek üzere, WISC-R Çocuklar için Zeka Ölçeği (Savaşır ve Şahin, 1995) kullanılmıştır. Türk standardizasyonunda sözel ZB puanın güvenirlik katsayıs1 .94, performans ZB puanınınki .91 ve toplam ZB puanınınki ise .92 olarak belirlenmiştir. Ölçek 6-16 yaş aralığında uygulanmakta ve uygulama süresi ortalama 60-70 dakikadır. Mevcut araştırmada kullanılan WISC-R, uygulama sertifikasına sahip uzman psikolog olan birinci araştırmacı tarafindan uygulanmıştır.

Kültürden Arındırılmış Öz-saygı Envanteri Çocuk Formu. Battle (1992) tarafından geliştirilen öz-saygı envanteri Genel Öz-saygı, Sosyal Özsayg1, Akademik Öz-saygı, Ailesel Öz-saygı ve Yalan alt boyutlarından ve 60 maddeden oluşmaktadır.

Orijinal ölçekte 5 boyut için iç tutarlılık katsayısının .66 ve .70 arasında değiştiği belirlenmiştir. Ölçeğin Türkçeye çevrilmesi ve dilsel eşdeğerlilik çalışması Davaslıgil (1999) tarafından yapılmıştır. Beş boyut için iç tutarlılık katsayılarının .51 ve .72 arasında değiştiği belirlenmiştir. Mevcut araştırmada genel Cronbach alfa .63 olarak hesaplanmıştır.

Olumlu - Olumsuz Mükemmeliyetçilik Ölçeği (OOMÖ). Kırdök tarafından 2004 yılında geliştirilen ölçek, olumlu ve olumsuz mükemmeliyetçiliği ölçen 2 alt boyut ve 17 maddeden oluşmaktadır. Kırdök (2004) tarafından 11-14 yaş grubu arasında yapılan ölçek geliştirme 
çalışmasında OOMÖ'nün olumlu ve olumsuz mükemmeliyetçilik alt boyutlarının Cronbach alfası .81 , ve .78 olarak hesaplanmıştır.

Kırdök'ün (2004) 11-14 yaş için geliştirmiş olduğu ölçeğin 8-9 yaş grubu için uygun olup olmadığını ortaya koymak amacıyla test maddeleriyle ilgili, yazarlar hariç 4 uzmanın görüşüne başvurulmuştur. Uzmanlardan gelen değerlendirmeler neticesinde yapılan kapsam geçerlik indeksi değeri, maddelerin tamamı için .99 olarak belirlenmiştir $(\mathrm{p}<.05)$. Böylece maddelerin tamamı belirtilen yaş grubuna uygun görülmüş fakat bazı ifade değişikliklerinin yapılması önerilmiştir. Daha sonra, ölçeğin 8-9 yaş grubuna uygunluğunu test etmek üzere ölçek maddeleri 2. ve 3. sinıfa devam eden toplam 91 öğrenciye uygulanmıştır. Sonuçlar revize edilen ölçeğin güvenirlik katsayısı hesaplanmış ve faktör analizi yapılmıştır. Yapılan analizlerin sonuçları revize edilen ölçek için 8-9 yaş grubundaki Cronbach alfa güvenirlik katsayısının .75 olduğunu ortaya koymuştur. $\mathrm{Bu}$ sonuç ölçeğin belirtilen yaş grubu için anlaş1lır ve uygun olduğunu göstermektedir. Revize edilen ölçeğin tüm maddeleri ölçeğin toplam puanı ile anlamlı korelasyona sahiptir $(\mathrm{p}<.05)$. Yapılan faktör analizi sonucunda revize edilen ölçeğin özgün ölçekte olduğu gibi iki alt boyuta sahip olduğu ve alt boyutlarda bulunan maddelerin özgün ölçektekilerle aynı dağılıma sahip olduğu gözlenmiştir. Mevcut çalışmada olumlu ve olumsuz mükemmeliyetçilik boyutlarının Cronbach alfası sırasıyla .84 ve .77 olarak hesaplanmıştır.

\section{İșlem}

1. 11-14 yaş grubu için geliştirilmiş olan OOMÖ'nin kullanılmasıyla ilgili gerekli izinler alındıktan sonra 8-9 yaş grubu için geçerlik güvenirlik çalışmaları yapılmıştır. İlk olarak ölçek kapsam geçerliği için uzman görüşüne gönderilmiştir. Uzmanlardan gelen yorum ve öneriler doğrultusunda ölçeğe son şekli verilmiş ve 8-9 yaş grubuna uygunluğunun test edilmesi için 91 öğrenci üzerinde çalışma yapılmıştır. Uygulamanın sonucunda revize edilen ölçeğin güvenirlik katsayısı hesaplanmış ve faktör analizi yapılmıştır. Analizler sonucunda revize edilen ölçeğin alt boyutları ve madde dağılımlarının asıl ölçekten farklılaşmadığı bulgulanmıştır.

2. Çalışma grubuna ilk yazar tarafından bireysel olarak Wisc-R uygulanmıştır.

3. OOMÖ ve Kültürden Arındırılmış Öz-saygı Envanteri çalışma grubuna sınıf ortamında uygulanmıştır.

4. Elde edilen veriler analiz edilmiş ve aşağıdaki bulgulara ulaşılmıştır. 


\section{BULGULAR}

Normalliği test etmek üzere yapılan Kolmogorov - Smirnov testi sonucunda, serbestlik derecesi 84 , anlamlılık düzeyi ise .200 (p>.05) olarak bulunmuştur (Cinsiyete göre analiz edildiğinde, erkekler için $\mathrm{KS}_{(54)}=.200$, $\mathrm{p}>.05$; kızlar için ise $\mathrm{KS}_{(30)}=.145, \mathrm{p}>.05$ olarak hesaplanmıştır) (Şekil 1.) $\mathrm{Bu}$ nedenle verilerin analizinde parametrik istatistik teknikleri kullanılmıştır.

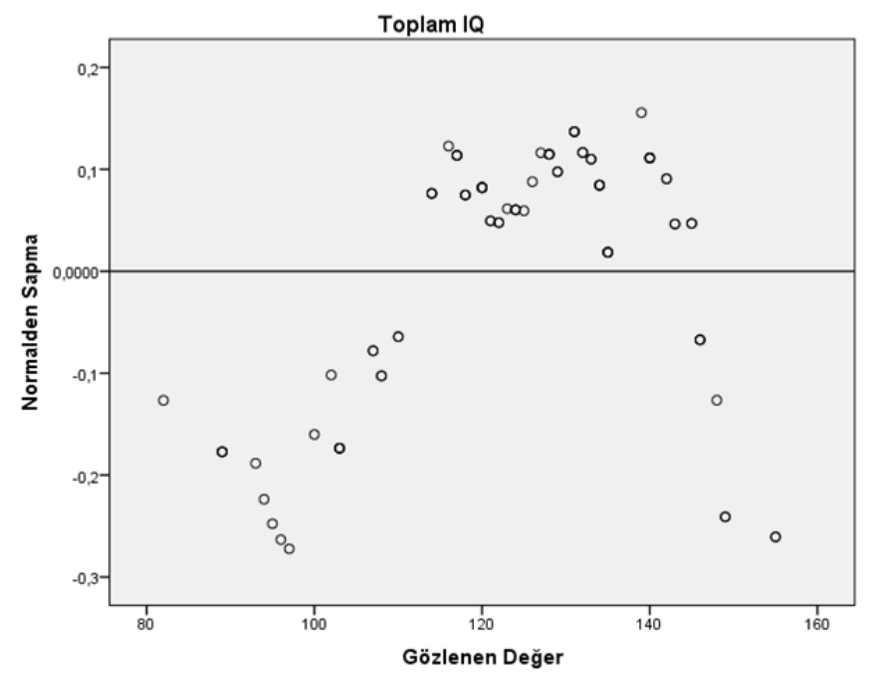

Şekil 1. Normal dă̆gllım grafĭğ

Tablo 1. Öğrencilerin sinıflara, zeka düzeylerine ve cinsiyetlerine göre dağıllımı

\begin{tabular}{|c|c|c|c|c|c|c|}
\hline \multirow{3}{*}{$\frac{\text { Sinif - Zeka }}{N=84}$} & \multicolumn{4}{|c|}{ Cinsiyet } & & \\
\hline & \multicolumn{2}{|c|}{ Erkek } & \multicolumn{2}{|c|}{$\mathrm{K}_{1 z}$} & \multicolumn{2}{|c|}{ Toplam } \\
\hline & $\mathrm{n}$ & $\%$ & $\mathrm{n}$ & $\%$ & $\mathrm{n}$ & $\%$ \\
\hline 2. Sınıf - Üstün & 18 & 41,9 & 9 & 20,9 & 27 & 62,8 \\
\hline 2. Sinıf - Normal & 10 & 24,4 & 5 & 12,2 & 15 & 36,6 \\
\hline 3. Sınıf - Üstün & 17 & 41,5 & 9 & 22,0 & 26 & 63,4 \\
\hline 3. Sinıf - Normal & 9 & 20,9 & 7 & 16,3 & 16 & 37,2 \\
\hline
\end{tabular}

2. sinıfa devam eden 42 öğrencinin $28^{\prime}$ i (18 üstün, 10 normal) erkek, 14 'ü (9 üstün, 5 normal) ise kızdır. Örneklem grubunda 3. sinıfa devam eden 42 öğrencinin 26’s1 (17 üstün, 9 normal) erkek, 16’s1 (9 üstün, 7 normal) ise kızdır. 
Tablo 2. Öz-saygı, olumlu - olumsuz mükemmeliyetçilik puanlarının cinsiyet değişkenine göre farklılaşıp farklılaşmadı̆̆ını belirlemek üzere yapılan bağımsız grup t testi sonuçları

\begin{tabular}{|c|c|c|c|c|c|c|}
\hline \multirow{2}{*}{ Puan } & \multirow{2}{*}{ Gruplar } & \multirow{2}{*}{ Ort. } & \multirow{2}{*}{$\mathrm{S}$} & \multicolumn{3}{|c|}{ t Testi } \\
\hline & & & & $\bar{t}$ & $\mathrm{Sd}$ & $\bar{p}$ \\
\hline \multirow{2}{*}{ Öz-sayg1 } & Erkek & 74,78 & 3,913 & \multirow{2}{*}{2,276} & \multirow{2}{*}{82} & \multirow{2}{*}{025} \\
\hline & $\mathrm{K} 1 \mathrm{z}$ & 72,67 & 4,350 & & & \\
\hline \multirow{2}{*}{ Olumlu M } & Erkek & 32,44 & 6,163 & \multirow[t]{2}{*}{$-2,783$} & \multirow[t]{2}{*}{82} & \multirow[t]{2}{*}{,007 } \\
\hline & $\begin{array}{l}\text { Kiz } \\
\text { Frkek }\end{array}$ & $\begin{array}{l}35,87 \\
15,67\end{array}$ & $\begin{array}{l}3,608 \\
5263\end{array}$ & & & \\
\hline Olumsuz M. & $\begin{array}{l}\text { Erkek } \\
\text { Kız }\end{array}$ & $\begin{array}{l}15,6 / \\
15,93\end{array}$ & $\begin{array}{l}5,263 \\
5,304\end{array}$ &,- 222 & 82 & ,825 \\
\hline
\end{tabular}

Tablo 2'den anlaşılacağı üzere Öz-sayg1 ve OOM puanlarının cinsiyet değişkenine göre farklılaşıp farklılaşmadığını belirlemek üzere yapılan bağımsız grup t-testi sonucunda Öz-saygı puanlarının cinsiyet değişkenine göre istatistiksel olarak anlamlı şekilde farklılaştığ 1 ve sonucun erkekler lehine olduğu görülmektedir $\left(\mathrm{t}{ }_{(82)}=2,276, \mathrm{p}<.05\right)$. Olumlu mükemmeliyetçilik puanlarının da cinsiyet değişkenine göre farklılaştığı ve sonucun kızlar lehine olduğu görülmektedir $\left(\mathrm{t}_{(82)}=-2,283, \mathrm{p}<.01\right)$. Olumsuz mükemmeliyetçilik puanlarının cinsiyet değişkenine göre değişip değişmediği incelendiğinde ise, cinsiyetler arasında olumlu mükemmeliyet-çilik düzeyleri açısından istatistiksel olarak anlamlı bir farka rastlanmamıştır $\left(t_{(82)}=-, 222\right.$, $\mathrm{p}<.05)$.

Tablo 3. Öz-saygl, olumlu - olumsuz mükemmeliyetçilik puanlarının zeka değişkenine göre farklılaşıp farklılaşmadı̆̆ını belirlemek üzere yapılan bağımsız grup $t$ testi sonuçları

\begin{tabular}{|c|c|c|c|c|c|c|}
\hline \multirow{2}{*}{ Puan } & \multirow{2}{*}{ Gruplar } & \multirow{2}{*}{ Ort. } & \multirow{2}{*}{$\mathrm{S}$} & \multicolumn{3}{|c|}{ t Testi } \\
\hline & & & & $t$ & $\mathrm{Sd}$ & $\mathrm{p}$ \\
\hline \multirow{2}{*}{ Öz-sayg1 } & Üstün & 74,96 & 3,710 & \multirow{2}{*}{2,804} & \multirow{2}{*}{82} & \multirow{2}{*}{,006 } \\
\hline & Normal & 72,42 & 4,485 & & & \\
\hline \multirow{2}{*}{ Olumlu M } & Üstün & 32,92 & 5,781 & \multirow{2}{*}{$-1,599$} & \multirow{2}{*}{82} & \multirow{2}{*}{ 114 } \\
\hline & Normal & 34,94 & 5,164 & & & \\
\hline \multirow{2}{*}{ Olumsuz M. } & Üstün & 15,74 & 5,478 & \multirow[t]{2}{*}{,- 059} & \multirow{2}{*}{82} & \multirow{2}{*}{ 953 } \\
\hline & Normal & 15,81 & 4,915 & & & \\
\hline
\end{tabular}

Tablo 3'ten anlaşılacağı üzere Öz-sayg1, OOM puanlarının zeka değişkenine göre farklılaşıp farklılaşmadığını belirlemek üzere yapılan bağımsız grup t-testi sonucunda Öz-saygı puanlarının zeka değişkenine göre istatiksel olarak anlamlı şekilde farklılaştığ öğrencilerin lehine olduğu bulgulanmıştır $\left(\mathrm{t}_{(82)}=2,804, \mathrm{p}<.01\right)$. OOM puan- 
larının zeka değişkenine göre değişip değişmediği incelendiğinde ise, IQ puanlar1 arasinda olumlu ( $\left.\mathrm{t}_{(82)}=-1,599, \mathrm{p}>.05\right)$ ve olumsuz $\left(\mathrm{t}{ }_{(82)}=-\right.$ $, 059, \mathrm{p}>.05)$ mükemmeliyetçilik düzeyleri açısından istatistiksel olarak anlamlı bir farka rastlanmamıştır.

Tablo 4. Zeka puanları ile öz-saygı ve olumlu - olumsuz mükemmeliyetçilik alt boyutları arasındaki ilişkiyi belirlemek üzere yapılan korelasyon analizi sonuçları

\begin{tabular}{|c|c|c|c|c|c|c|c|c|}
\hline $\mathrm{N}=50$ & $\begin{array}{l}\text { Toplam } \\
\text { IQ }\end{array}$ & $\begin{array}{c}\text { Genel } \\
\text { Öz-sayg1 }\end{array}$ & $\begin{array}{c}\text { Sosyal } \\
\text { Öz-sayg1 }\end{array}$ & $\begin{array}{c}\text { Akademik } \\
\text { Öz-sayg1 }\end{array}$ & $\begin{array}{c}\text { Ailesel } \\
\text { Öz-sayg1 }\end{array}$ & Yalan & $\begin{array}{c}\text { Toplam } \\
\text { Öz-sayg1 }\end{array}$ & $\begin{array}{l}\text { Olumlu } \\
\text { M. }\end{array}$ \\
\hline \multicolumn{9}{|l|}{ Toplam IQ } \\
\hline $\begin{array}{c}\text { Genel } \\
\text { Öz-sayg1 }\end{array}$ &, $269(*)$ & & & & & & & \\
\hline $\begin{array}{c}\text { Sosyal } \\
\text { Öz-sayg1 }\end{array}$ &,- 003 & ,321 & & & & & & \\
\hline $\begin{array}{l}\text { Akademik } \\
\text { Öz-sayg1 }\end{array}$ &, $303(* *)$ & ,362 & ,261 & & & & & \\
\hline $\begin{array}{l}\text { Ailesel } \\
\text { Öz-sayg1 }\end{array}$ & ,068 & ,217 & ,091 & ,264 & & & & \\
\hline Yalan &, $247(*)$ & ,112 & ,090 & ,335 & ,108 & & & \\
\hline $\begin{array}{l}\text { Toplam } \\
\text { Öz-sayg1 }\end{array}$ &, $257(*)$ &, $855(* *)$ &, $624(* *)$ &, $632(* *)$ &, $462(* *)$ &, 211 & & \\
\hline Olumlu M &,- 158 &,- 088 &,- 025 &,- 038 & ,066 &,- 392 &,- 056 & \\
\hline $\begin{array}{c}\text { Olumsuz } \\
\text { M. }\end{array}$ & ,013 &,- 349 &,- 178 &,- 165 &,- 100 &, 151 & $\begin{array}{c}- \\
337(* *)\end{array}$ & ,005 \\
\hline
\end{tabular}

Öğrencilerin zeka puanları ile öz-saygı ve OOM alt boyutları arasındaki ilişki Pearson Çarpım Moment Korelasyonu analizi yapılarak incelenmiştir. Elde edilen bulgular sonucunda toplam IQ ile öz-sayg1 alt boyutlarından genel öz-sayg1 $(\mathrm{r}=, 269, \mathrm{p}<.05)$, akademik öz-sayg1 $(\mathrm{r}=, 303, \mathrm{p}<.01)$, yalan boyutları $(\mathrm{r}=, 247, \mathrm{p}<.05)$ ve toplam öz-sayg1 $(\mathrm{r}=, 257, \mathrm{p}<.05)$ puanları arasında olumlu ve istatistiksel olarak anlamlı bir ilişki olduğu saptanmıştır. Öz-sayg1 Envanterinin kendi alt boyutları arasındaki korelasyon analizlerine göre, toplam öz-sayg1 puanları ile genel $(\mathrm{r}=, 855, \mathrm{p}<.01)$, sosyal $(\mathrm{r}=, 624$, $\mathrm{p}<.01)$, akademik $(\mathrm{r}=, 632, \mathrm{p}<.01)$ ve ailesel $(\mathrm{r}=, 462, \mathrm{p}<.01)$ öz-sayg1 alt boyutları arasında olumlu ve anlamlı ilişki saptanmıştır. Öz-saygı Envanteri toplam puanının olumsuz mükemmeliyetçilik toplam puanı arasında negatif yönde bir ilişki olduğu saptanmıştır $(\mathrm{r}=-, 337, \mathrm{p}<.01)$. 


\section{TARTIŞMA VE SONUÇ}

$\mathrm{Bu}$ çalışmada, üstün zekalı ve normal gelişim gösteren ikinci ve üçüncü sınıf öğrencilerinin öz-sayg1 ve mükemmeliyetçilik düzeyleri incelenmiştir. Çalışma bulguları, öz-saygının, cinsiyete ve zekaya bağlı olarak değişirken, mükemmeliyetçiliğin zekaya bağlı olarak değişmediğini buna karşın kızların olumlu mükemmeliyetçilik puanlarının erkeklerden yüksek olduğunu göstermiştir. Araştırmanın yapıldığı çalışma grubundaki öğrenciler, farklılaştırılmış bir eğitimin uygulandığı bir pilot okula devam ettiklerinden sonuçlar, bu okulda verilen özel eğitim de göz önünde bulundurularak tartışılmıştır.

Alan yazında öz-saygı ve cinsiyet arasındaki ilişkileri inceleyen araştırmaların sonuçları arasında çelişkiler bulunmaktadır. Ergenlerle yapılan farklı çalışmalar, erkek ergenlerin benlik kavramlarının kızlara göre daha olumlu olduğunu desteklemektedir (Dinç, 1992; Hatipoğlu, 1996). Bunlara benzer birçok araştırma bulgusu öz-saygı düzeyinin erkekler lehine daha yüksek olduğuna işaret etse de (Güçray, 1989; Seber ve Satılmış, 1989); tersi bulgulara ulaşan araştırmalar da vardır (Seyhan-Maşrabacı, 1994; Zırh, 1995).

Öz-saygı, cinsiyet ve zeka değişkenleri açısından ele alındığında da alanyazındaki çalışmaların bulgularının farklılaştığı görülmektedir. Bencik (2006) tarafindan üstün ve normal gelişim gösteren öğrenciler üzerinde yapılan araştırmada, kız öğrencilerin öz-saygılarının daha yüksek olduğu bulunmuştur. Cinsiyet değişkeninin araştırıldığı bir araştırmada ise üstün zekalı kız öğrencilerin, öz-saygılarının normal gelişim gösteren kızlardan daha düşük olduğu ve farkın öğrencilerin yaşları arttıkça arttığı bulunmuştur (Lea-Wood, 1995). Mevcut çalışmada, sonucun erkeklerin lehine olduğu görülmektedir. $\mathrm{Bu}$ durumun sebepleri arasında, erkeklerin Türk toplumu tarafindan daha çok desteklenmesi ve bireysel özelliklerini ifade etmeleri konusunda cesaretlendirilmeleri sayılabilir. Ancak öz-saygıdan bahsederken cinsiyet, yaş, kültürel yapılanma, özel eğitim ve zeka düzeyi gibi değişkenlerin de iyi irdelenmesi gerekmektedir.

Üstün zekalı çocukların öz-saygı kavramlarının olumluluk düzeyini normal gelişim gösteren çocuklarla karşılaştırmalı olarak inceleyen araştırmaların bulguları tartışmalıdır. Bazı araştırmalar üstün zekalı çocuklar lehine olumlu öz-sayg1 değerlerinden bahsederken (Lehman ve Erdwins, 1981; Kelly ve Colangelo, 1984) diğer araştırmalar anlamlı bir farkın olmadığını göstermektedir (Karnes ve Wherry, 1981; Loeb ve Jay, 1987; Burak, 1995). Hoge ve Renzulli (1993), genel olarak üstün yetenekli çocukların, normal gruba göre çok az bir farklılıkla daha olumlu öz-saygıya sahip olduklarını kaydetmişlerdir. Mevcut araştırmada da bulgular bu sonuçları desteklemektedir. Uzmanlar, üstün zekalı çocukların zeka düzeylerinin yüksek olmasının, etkili savunma mekanizmaları oluşturma- 
larına yardım ettiğini ve karşılaşılan olumsuzlukların üstesinden daha kolay gelme becerileri geliştirmelerinde daha etkili olduğunu savunmaktadır. Üstün zekalı çocukların benlik kavramlarının daha olumlu düzeyde olmasını bu şekilde açıklamaktadırlar (Metin, 1999; Ataman, 2004).

Üstün zekalı öğrencilerin öz-saygı düzeylerinin normal gelişim gösteren yaşıtlarına göre daha yüksek bulunmasının nedeninin, farklılaştırılmış eğitimden kaynaklanabileceği düşünülmektedir. Yürük'ün (2003) Bilim Sanat Merkezlerine devam eden 132 üstün zekalı ve 146 normal gelişim gösteren öğrencilerin benlik saygılarını karşılaştırdığ 1 araştırmada da, üstün zekalı öğrencilerin lehine sonuçlar elde edilmiştir. Her ne kadar Yürük'ün çalışmasına da mevcut araştırmaya da özel eğitim almayan üstün zekalı öğrenciler dahil edilmemiş olsa da, Karnes ve Wherry (1981) özel bir eğitim ortamı içinde olan üstün zekalı çocukların normal eğitim ortamında olanlara göre, genel benlik kavramlarının daha olumlu olduğu görüşüne sahiptir. $\mathrm{Bu}$ görüşlerin desteklenmesi için ampirik çalışmaların yapılması faydalı olacaktır. Ayrıca yapılan bu araştırmalarda farklı sosyoekonomik düzeyden gelen üstün zekalı çocukların da incelenmesinin yararlı olacağı düşünülmektedir (Metin ve Bencik, 2012).

Mükemmeliyetçilik düzeylerinin cinsiyete göre değişimi analiz edildiğinde, kız öğrencilerin olumlu mükemmeliyetçilik düzeylerinin erkek öğrencilerden daha yüksek olduğu, olumsuz mükemmeliyetçilik açısından ise farkın olmadığ gözlenmiştir. Bu bulgulara paralel olarak Mısırl1Taşdemir'in (2003) üstün zekalı çocuklarda sınav kaygısı ile mükemmeliyetçilik arasındaki ilişkiyi saptamak amacıyla yapmış olduğu araştırmada, erkeklerin kızlara oranla daha fazla olumsuz mükemmeliyetçilik sergiledikleri, ve daha yüksek standartlara sahip olma eğilimde oldukları görülmektedir. Ataerkil toplumlarda erkeklerden daha yüksek beklenti içerisinde olunması bu durumun nedenleri arasında olabilir. Ancak mevcut çalışma da dahil olmak üzere pek çok araştırma (Preusser, Rice ve Ashby, 1994; Ashby ve Rice, 2002) mükemmeliyetçilik ile öz-sayg1 arasındaki negatif ilişkiden bahsetmektedir. Bu bağlamda erkeklerin özsayg1 düzeylerinin kızlara oranla anlamlı derecede daha yüksek olması, neden olumsuz mükemmeliyetçilik düzeylerinin yüksek çıkmadığını açıklamaktadır. $\mathrm{Bu}$ bulgular 1şı̆̆ında öz-saygının sağlılı bir şekilde gelişmesi için yapılan sosyal-duygusal beceriler dersinin dolaylı olarak erkeklerdeki olumsuz mükemmeliyetçiliğin oluşmasını engellediği düşünülebilir. Bunun sınanabilmesi için farklılaştırılmış eğitim almayan erkek öğrencilerin mükemmeliyetçilik düzeylerinin araştırılması önerilmektedir.

Mevcut araştırmada zeka ile mükemmeliyetçilik düzeyleri arasında anlamlı bir ilişki bulunamamıştır. Bununla birlikte alanyazında böylesi bir ilişkinin var olduğunu gösteren araştırmalar yer almaktadır. LoCicero ve Ashby, (2000) tarafindan 83 üstün zekalı çocukla yapılan çalışmada örneklem uyumlu ve uyumsuz mükemmeliyetçilik açısından incelenmiş ve 
çoğunluğunun uyumlu mükemmeliyetçiler olduğu bulunmuştur. Fakat bu ve benzeri bulguların aksine üstün zekalı çocukların genellikle olumsuz mükemmeliyetçiler oldukları varsayılmaktadır. Zeka ve cinsiyet bakımından mükemmeliyetçilik araştırıldığında, Baker (1996), üstün zekalı kızların üstün zekalı erkeklerden ve diğer normal gelişim gösteren yaşıtlarından daha yüksek mükemmeliyetçilik düzeylerine sahip olduklarını bulmuştur. LeanaTaşcılar, Özyaprak, Güçyeter, Kanlı ve Camc1-Erdoğan (2014) tarafindan ilköğretim düzeyindeki üstün öğrencilerle yapılan çalışma sonuçları, üstün zekalı ve kız öğrencilerin sosyal kaynaklı mükemmeliyetçilik düzeyinin erkeklerden daha düşük olduğunu göstermektedir.

Parker ve Mills (1996) üstün zekalı olan ve normal gelişim gösteren öğrencilerin çok boyutlu mükemmeliyetçilik ölçeğinden aldıkları puanlar arasında anlamlı fark tespit edememiştir. Parker (2000) yaygın inancın aksine üstün yeteneklilerde olumsuz mükemmeliyetçilik eğilimlerinin daha fazla olmadığını belirtmiştir. Üstün yeteneklilerde var olan üstünlük çabasının, başarıya teşvik edici bir güç olduğunu, başarısızlık ve kişisel problemleri ortaya çıkaran olumsuz mükemmeliyetçilik olmadığını ortaya koymuştur. Mevcut çalışmada da buna paralel sonuçlar çıkması, bu öğrencilere sunulan farklılaştırılmış eğitim programının mükemmeliyetçilikle nasıl baş edileceğini öğretmede olumlu etkiler yarattığını düşündürtmektedir. Araştırmanın başka sınıf düzeylerine ve farklı eğitimler alan üstün zekalılara da yapılmasının daha genellenebilir sonuçların elde edilmesini sağlayacağı düşünülmektedir.

Wisc - R zeka testi toplam puanları, öz-sayg1 ve mükemmeliyetçilik ölçekleri arasındaki ilişkiler incelendiğinde, toplam IQ puanları ile genel, akademik, yalan ve toplam öz-saygı puanları arasında olumlu yönde bir ilişkinin olduğu saptanmıştır. Buna karşın toplam öz-saygı puanları ile olumsuz mükemmeliyetçilik arasında olumsuz yönde bir ilişkinin olduğu belirlenmiştir. Bu bulgu, daha önce de değinildiği gibi Ashby ve Rice'ın (1999) uyumlu olmayan mükemmeliyetçilik ile öz-sayg1 arasında olumsuz ilişki bulgusunu desteklemektedir.

Sonuç olarak, cinsiyet değişkenine göre, erkeklerin öz-sayg1 düzeylerinin, kızların ise olumlu mükemmeliyetçilik düzeylerinin daha yüksek olduğu görülmektedir. Üstün zekalı ve normal gelişim gösteren öğrencilerin öz-sayg1 ve mükemmeliyetçilik düzeyleri incelendiğinde, üstün öğrencilerin daha yüksek öz-sayg1 düzeylerine sahip oldukları ancak mükemmeliyetçilik düzeyleri ile zeka arasında bir ilişkinin olmadığ 1 saptanmıştır. Araştırmanın farklılaştırılmış eğitim sunulan özel bir grupta yürütülmüş olması, sonuçların genelleştirebilmesi için bir sınırlık oluşturmaktadır.

Araştırmada incelenen mükemmeliyetçilik ve öz-sayg1 bireylerin yaşamlarına yön veren çok önemli iki kavramdır. Bu kavramların, öğrencilerin eğitim hayatlarını, başarılarını, beklentilerini ve motivasyonlarını 
da etkilediği bilinmektedir. $\mathrm{Bu}$ nedenle farklılaştırılmış eğitim programlarında olumlu mükemmeliyetçiliğin desteklenmesine ve özsaygının da artırılmasına yönelik çalışmaların yapılmasının faydalı olabileceği düşünülmektedir. Nitekim bu araştırmada ele alınan grupta uygulanan sosyal beceri eğitiminin etkili olduğu, bu nedenle zeka değişkeni açısından mükemmeliyetçilik düzeyin farklılık göstermediğ düşünülmektedir. Benzer şekilde öz-saygının yüksek olması olumsuz mükemmeliyetçiliğe ket vurmaktadır. Bu bulguların genelleştirilebilmesi ve uygulamada etkili bir şekilde kullanılabilmeleri için aşağıdaki öneriler getirilebilir:

Mevcut araştırmaya benzer bir araştırmanın daha büyük bir örneklemde yapılması, elde edilen bulguların genellenebilmesi adına daha yararlı olacaktır. Mevcut araştırmadaki çalışma grubu bir proje okulunda eğitimlerine devam eden öğrencilerle sınırlandırılmıştır. Aldıkları farklılaştırılmış eğitim programının en önemli derslerinden bir tanesi "Sosyal-Duygusal Gelişim"i desteklemektedir. Bu bağlamda, araştırmanın özel eğitim almayan üstün ve normal gelişim gösteren çocukların bulunduğu bir örneklemde yinelenmesinin faydalı olacağı düşünülmektedir. Alanyazında, öz-saygı ve mükemmeliyetçilik düzeylerinin yaş ve sınıfa bağlı olarak değişebildiğini gösteren bulgular bulunmaktadır. Bu nedenle, mevcut araştırmanın sonuçlarının daha iyi anlaşılabilmesi adına, çalışmanın boylamsal olarak tekrarlanmasının faydalı olacağı düşünülmektedir. Ayrıca, öğrencilerin olumsuz mükemmeliyetçilikle baş edebilmelerini ve sağlıklı özsayg1 geliştirebilmelerini sağlamak için gerekli eğitimlerin küçük yaştan itibaren verilmesinin yararlı olacağı düşünülmektedir.

\section{KAYNAKLAR}

Akan, A. (2001). "7- 12 Yas Cocuklarında Görülen Uyum ve Davranış Bozuklukları ve Benlik Saygısı İlişkisi." Yayınlanmamış yüksek lisans tezi, İstanbul Üniversitesi, Sosyal Bilimler Enstitüsü, İstanbul.

Antony, M. M. ve Swinson, R. P. (2000). Mükemmeliyetçilik Dost Sandlğımız Düşman. (Çev.: A. Açıkgöz). İstanbul: Kuraldışı Yayıncılık.

Ashby, J. \& Rice, K. (1999). "Perfectionism, dysfunctional attitudes, and selfesteem: A structural equations analysis." Poster session presented at the Annual Meeting of the American Psychological Association, Boston, MA.

Ashby, J. \& Rice, K. (2002). Perfectionism, dysfunctional attidutes and self-esteem: a structural equations analysis, Journal of Counseling and Development, 80(2), 197-208.

Ataman, A. (2004). Üstün Yetenekli/Zekalı Çocuk ile Yaşamak, R. Şirin, A. Kulaksızoğlu (Ed.) Üstün Yetenekli Çocuklar Seçilmiş Makaleler Kitabı, (ss. 56-72). İstanbul: Çocuk Vakfı Yayınları: 63, I. Türkiye Üstün Yetenekli Çocuklar Kongresi Yayın Dizisi:1. 
Avşaroğlu, S. (2007). "Üniversite Öğrencilerinin Karar Vermede Öz-saygı, Karar Verme ve Stresle Başaçıkma Stillerinin Benlik Saygısı ve Bazı Değişkenler Açısından İncelenmesi." Yayınlanmamış yüksek lisans tezi, Selçuk Üniversitesi, Sosyal Bilimler Enstitüsü, Konya.

Baker, J. A. (1996). Everyday stressors of academically gifted adolescents. Journal of Secondary Gifted Education, 7, 356-368.

Battle, J. (1992). Culture-free self-esteem inventories: examiner's manual ( ${ }^{\text {nd }}$ Ed.). Austin, TX: PRO-ED.

Bencik, S., (2006). "Üstün Yetenekli Çocuklarda Mükemmeliyetçilik ve Benlik Algısı Arasındaki İlişkinin İncelenmesi." Yayınlanmamış yüksek lisans tezi, Hacettepe Üniversitesi, Sosyal Bilimler Enstitüsü, Ankara.

Bieling, P. J., Israeli, A., Smith, J. \& Antony, M. M. (2003). Making the grade: The behavioral consequences of perfectionism in the classroom. Personality and Individual Differences, 35, 163-178.

Burak, E. M. (1995). "Üstün Yetenekli Öğrencilerin Benlik Kavramlarına İlișkin Bir Araştırma." Yayınlanmamış yüksek lisans tezi, Ankara Üniversitesi, Sosyal Bilimler Enstitüsü, Ankara.

Chan, D.W. (2003). Adjustment problems and multiple intelligences among gifted students in Hong Kong: the development of the revised student adjustment problems inventory. High Ability Studies, 14, 41-54.

Clark, B. (2002). Growing up gifted (6 $6^{\text {th }}$ Ed.). New Jersey: Pearson Education Inc.

Davasligil, U. (1999). "Enhancement of creativity: An important problem in Turkish education system. "Paper presented at World Council for Gifted and Talented Children, Istanbul.

Davaslıgil, U. (2004). Üstün Çocuklar, R. Şirin, A. Kulaksızoğlu ve A. E. Bilgili (Ed.), Üstün Yetenekli Çocuklar: Seçilmiş Makaleler Kitabl, (ss. 211- 218). İstanbul: Çocuk Vakfı Yayınları: 63, I. Türkiye Üstün Yetenekli Çocuklar Kongresi Yayın Dizisi:1.

Davis, G.A. (2006). Gifted children and gifted education: A practical guide for teacher and parents. Scottsdale, AZ: Great Potential Press, Inc.

Dinç, F. (1992). "Cinsiyetleri Farklı Lise Öğrencilerinin Benlik Algı Düzeylerinin Özsaygı Düzeylerine Etkisi." Yayınlanmamış yüksek lisans tezi, Hacettepe Üniversitesi, Sosyal Bilimler Enstitüsü, Ankara.

Frost, R. O., Marten, P., Lahart, C. \& Rosenblate, R. (1990). The dimensions of perfectionism. Cognitive Therapy and Research, 14, 449-468.

Greenspan, T. S. (2000). Healthy perfectionism is an oxymoron. Journal of Secondary Gifted Education, 11(4), 197-209.

Güçray, S.S. (1989). "Çocuk Yuvasında ve Ailesi Yanında Kalan 9-10-11 yaş Çocuklarının Öz - Saygı Gelişimini Etkileyen Bazı Faktörler.” Yayınlanmamış doktora tezi, Hacettepe Üniversitesi, Sosyal Bilimler Enstitüsü, Ankara.

Hatipoğlu, Z. (1996). "Ergenlik Çağındaki Öğrencilerin Benlik Tasarım Düzeyleri ile Algılanan Anne Davranışları Arasındaki İlişkinin İncelenmesi." Yayınlanmamış yüksek lisans tezi, İstanbul Üniversitesi, Sosyal Bilimler Enstitüsü, İstanbul.

Hoge, R. D. \& Renzulli, J. S. (1993). Exploring the link between giftedness and selfconcept. Review of Educational Research, 63, 449-465.

Hollingworth, L.S. (1926). Gifted children: Their nature and nurture. New York: Macmillan. 
Hollingworth, L.S. (1942). Children above 180 IQ Stanford-Binet-origin and development. Yonkerson-Hudson, NY: World Book.

James, W. (1948). Psychology. New York: The World Publishing Company.

Jones, S. (1973). Self and interpersonel evaluations: esteem theories versus consistency theories. Psychological Bulletin, 79, 185-199.

Kanlı, E. (2007). "Fen ve Teknoloji Öğretiminde Probleme Dayalı Öğrenmenin Üstün ve Normal Zihin Düzeyindeki Öğrencilerin Erişi, Yaratıcı Düşünme ve Motivasyon Düzeylerine Etkisi." Yayınlanmamış yüksek lisans tezi, İstanbul Üniversitesi, Sosyal Bilimler Enstitüsü, İstanbul.

Karnes, F. A. \& Wherry, J. N. (1981). Self-concepts of gifted students as measured by the Piers-Harris children's self concept scale. Psychological Reports, 49, 903-906.

Kelly, K.R. \& Colangelo, N (1984). Academic and social self-concepts of gifted, general and special students. Exceptional Children, 50, 551-554.

Kırdök, O. (2004). "Olumlu ve Olumsuz Mükemmeliyetçilik Ölçeği Geliștirme Çalışması." Yayınlanmamış yüksek lisans tezi, Çukurova Üniversitesi, Sosyal Bilimler Enstitüsü, Adana.

Lawrence, D. (2006). Enhancing self-esteem in the classroom. USA: Paul Chapman Publishing.

Leana-Taşcılar, M. Z. ve Cinan, S. (2012). Üstün Zekalı ve Normal Çocuklarda Yönetsel Fonksiyonlar: Londra Kulesi Testi. Psikoloji Çalışmaları Dergisi, 32,13-30.

Leana-Taşcılar, M.Z., Özyaprak, M., Güçyeter, S., Kanlı, E. ve Camcı-Erdoğan, S. (2014). Üstün Zekalı ve Yetenekli Çocuklarda Mükemmeliyetçiliğin Değerlendirilmesi. Hasan Ali Yücel Ĕgitim Fakültesi Dergisi, 11, 31-45.

Lea-Wood, S.S. (1995) Self-Esteem of gifted adolescent girls in Australian schools. Roeper Review, 17 (3), 195.

Lehman, E. B. \& Edwins, C. J. (1981). The social and emotional adjustment of young intellectually gifted children. Gifted Child Quarterly, 25, 134-137.

Litauer, F. \& Litauer, M. (1997), Kişilik bulmacası: Birlikte Çalıştığımız İnsanları Anlamak. (Çev. H. B. Çelik). İstanbul: Sistem Yayıncılık.

LoCicero, K. \& Ashby, J.S. (2000). Multidimentional perfectionism in middle school age gifted students: a comparison to peers from the general cohort. Roeper Review, 22 (3), 12-17.

Loeb, R. C. \& Jay, G. (1987). Self-concept in gifted children: Differential impact in boys and girls. Gifted Child Quarterly, 1, 9-14.

Maker, J. (2003). New directions in enrichment and acceleration. In N. Colangelo \& G. Davis (Eds.), Handbook of gifted education (pp. 163 - 173). Boston: Allyn and Bacon.

Metin, N. (1999). Üstün Yetenekli Çocuklar. Ankara: Öz-Aşama Matbaacılık.

Metin, N. ve Bencik, S. (2012). Bilim Sanat Merkezlerine Devam Eden 12-14 Yaş Grubu Üstün Yetenekli Çocukların Benlik Algılarının İncelenmesi. Eğitim ve Bilim, 37 (163), 1-16.

Mısırl-Taşdemir, Ö. (2003). "Üstün Yetenekli Çocuklarda, Mükemmeliyetçilik, Sınav Kaygısı, Benlik Saygısı, Kontrol Odağı, Öz Yeterlilik ve Problem Çözme Becerileri Arasındaki İlişkinin İncelenmesi." Yayınlanmamış yüksek lisans tezi, Karadeniz Teknik Üniversitesi, Sosyal Bilimler Enstitüsü,Trabzon. 
Oran-Pamir, Ç. (2008). "Lise Öğrencilerinin Mükemmeliyetçlik Düzeyleri ile Anne Baba Tutumları Arasındaki İlişki." Yayınlanmamış yüksek lisans tezi, Muğla Üniversitesi, Sosyal Bilimler Enstitüsü, Muğla.

Orange, C. (1997). Gifted stundents and perfectionism, Roeper Review, 20(1), 1-9.

Parker, W.D. \& Mills, C.J. (1996). The incidence of perfectionism in gfted students. Gifted Child Quarterly, 40 (4), 194-200.

Parker, W. D. (2000). Healthy perfectionism in the gifted. Journal of Secondary Gifted Education, 11,173-183.

Pope, A.W., Mchale, S. M. \& Craighead,W. E. (1988). Self-esteem psychology. Canada: Pergoman Pres.

Preusser, K. J., Rice, K. G. \& Ashby, J.S. (1994). The role of self-esteem in mediaty: The perfectionism-depression connection, Journal of College Student Development, 35, 412-421.

Robinson, A. \& Clinkenbeard, P. R. (1998). Giftedness: An exceptionality. Annual Review of Psychology, 49, 117-39.

Saranlı, A. G. ve Metin, N. (2012). Üstün Yetenekli Çocuklarda Gözlenen SosyalDuygusal Sorunlar. Ankara Üniversitesi Eğitim Bilimleri Fakültesi Dergisi, 45 (1),139-163.

Savaşır, I. ve Şahin, N. (1995). Wechsler Çocuklar İçin Zeka Ölçeği. Ankara: Türk Psikologlar Derneği.

Schuler, P. A. (2000). Perfectionism and gifted adolescents. Journal of Secondary Gifted Education, 11, 183-197.

Seber, G. ve Satılmış, G. (1989). Yetiştirme Yurdunda Yaşayanlarda Benlik Saygısı. Psikoloji Dergisi, 7(23), 68-73.

Seyhan-Maşrabacı, T. (1994). "Hacettepe Üniversitesi Birinci Sınıf Öğrencilerinin Özsaygı Düzeylerinin Bazı Değişkenlere Göre İncelenmesi." Yayınlanmamış doktora tezi, Hacettepe Üniversitesi, Sosyal Bilimler Enstitüsü, Ankara.

Silverman, L. K. (1993). Social development, leadership, and gender issues. In L. K. Silverman (Ed.), Counseling the gifted and talented, (s. 291 - 327). Denver, CO: Love Publishing.

Silverman, L. K. (1999). Perfectionism. Gifted Education International, 13, 216225.

Sternberg, R. (1997). Successful intelligence: How practical and creative intelligence determine success in life. USA: Plume Pub.

Sternberg, R. J. (2003). Wisdom, intelligence and creativity synthesized. New York: Cambridge University Press.

Yıldırım, A. ve Şimşek, H. (2008). Sosyal Bilimlerde Nitel Araştırma Yöntemleri. Ankara: Seçkin Yayıncılık.

Yürük, A. (2003). "İlköğretim Çağındaki Üstün Yetenekli Öğrencilerle Normal Gelişim Gösteren Öğrencilerin Benlik Saygılarının Karşılaştırılması." Yayınlanmamış yüksek lisans tezi, Hacettepe Üniversitesi, Sağlık Bilimleri Enstitüsü, Ankara.

Zırh, S. (1995). "Eğitim Fakültesi Öğrencilerinin Benlik İmajının Çeşitli Değişkenler Açısından İncelenmesi." Yayınlanmamış yüksek lisans tezi, Hacettepe Üniversitesi, Sosyal Bilimler Enstitüsü, Ankara. 